\title{
Food Allergens: The New Challenge
}

\author{
Eduardo Padilla-Camberos ${ }^{1 *}$, Carla Patricia Barragan-Alvarez ${ }^{1}$, Maria del Rosario Gallegos-Ortiz ${ }^{2}$ and Jose \\ Miguel Flores-Fernandez ${ }^{2,3}$ \\ ${ }^{1}$ Unit of Medical and Pharmaceutical Biotechnology, Center for Research and Assistance in Technology and Design of Jalisco, AC (CIATEJ), Mexico \\ ${ }^{2}$ Division of Engineering in Food Industries and Sustainable Agricultural Innovation, Tecnológico de Estudios Superiores de Villa Guerrero, Mexico \\ ${ }^{3}$ Department of Biochemistry, University of Alberta, Canada
}

Submission: November 01, 2017; Published: December 19, 2017

*Corresponding author: Eduardo Padilla-Camberos, Center for Research and Assistance in Technology and Design of Jalisco, AC (CIATEJ), Normalistas 800, Guadalajara, 44270, Mexico, Tel/Fax: (52)33 33455200; Email: epadilla@ciatej.mx

Abstract

The control of allergens in the food industry involves a series of activities aimed at avoiding the health problems in consumers; international legislation emphasizes the labeling of food allergens however it differs between countries. It is relevant due to the incremental food exchange around the world. This review focuses on the strategic points where companies must take more care for the proper management of allergens.

Keywords: Food allergens; Legislation; Challenge

Abbreviations: FALCPA: Food Allergens Labeling and Consumer Protection Act; EU: European Union

\section{Introduction}

Allergens can be found in food such as certain proteins, responsible for allergic reactions to sensitive people and it is estimated about $4 \%$ of the world population display food allergy and is more frequent in children (3-8\%). In addition, the trend of food allergy has been increasing in developing countries, being a subject of great concern in the industrialized countries. As part of globalization and global food exchange, the food industry has a new and great challenge: allergen control.

Food allergy is usually managed by preventive practices of exposition to allergens or symptoms treatment; however, to avoid presence of allergens in food implies a significant challenge for industries because the presence of these is related to multiple factors, such as food composition, manufacturing, transportation, storage, among others. In addition, guidelines associated to allergen control and food labeling is different in each country.

\section{Allergens}

\section{Impact and Legislation}

Allergens may be present in food as natural components and cannot be removed by cooking; there are mainly eight foods ingredients considered as allergenic: peanut, milk, egg, soy, tree nuts, fish, crustacean shellfish, and wheat $[1,2]$. The relative importance of these food ingredients varies according to age and geographic location of the consumer.

Among the manifestations generated by an allergy associated with food allergens, the symptoms in the digestive, respiratory, cardiovascular systems or cutaneous reactions stand out. The severity of symptoms varies from a mild skin irritation to severe anaphylaxis and systemic shock. The symptoms of food allergy are directly proportional to the amount of food consumed or to other factors such as asthma and usage of medicines like steroids and antihistamines [3]. Because there is no cure for people with food allergy; the best way to protect the susceptible population is preventive practices of exposure to allergens.

More than 200 foods with allergenic potential have been documented, where eight of them generate $90 \%$ of all food allergies [4]. Due to the impact of food allergens on human health, several countries and international organizations have recognized the importance the need to focus regulation on allergen labeling on a limited set of priority allergens of providing this information through the enactment of laws, regulations or standards for the labeling of allergens in food. However, there are notable differences in the regulation of the different countries to be overcome [5]. 
Several countries have been based their regulatory framework on international standards such as the Codex Alimentarius, Directive 2003/89/EC of the European Union (EU) and the Food Allergen Labeling and Consumer Protection Act (FALCPA). This list of standards foods or food groups are considered as "priority" allergens and demand the identification of these allergens in a simple language on food labels that contain them as ingredients [6].

Some products as celery, sesame and lupine are considered as allergens in the European Union, besides the eight-food established by the Codex Alimentarius. Canada also includes sesame and lupine, while Japan includes only allergens of local prevalence [7].

The categorization of food allergens represents a problem to establish a standardized label, because tree nuts in the EU are considered seeds, while in the United States and Canada, those are tree nuts. Another example occurs with the group of mollusks because some places classify them as fishes while in others it is not clear.

In most countries, legislation on allergen labeling applies only to pre-packaged foods. The European Union legislation from 2014 also began to require it for unpacked food sold in bakeries and food establishments. [8].

Currently, one of the biggest challenges for the dependencies in charge of labeling regulation of food allergens is to guarantee the allergens are being declared with appropriate terminology that can be easily understood by the consumer [9].

Management and Control of Food Allergens in Industry

Allergen labeling includes both the declaration of allergenic ingredients and precautionary statement of the possible in advert presence of allergens due to cross-contamination during food production known as "may contain", although these precautionary allergen labeling are generally not based on an risk analysis and some countries have banned their use [10].

Of even greater concern for sensitive consumers is that a food allergen might be hidden in a processed food. This can occur when an ingredient derived from an allergenic food is labeled using a scientific term as casein instead of milk or oval bum in instead of egg or by using a broad and uninformative term such as textured vegetable protein instead of soy [1].

Food processing can be an allergen source by crosscontamination. This happens when the equipment is shared to process both allergen food and allergen-free products; as well as reprocessing is another common source. In addition, changes in the formulation or bad manufacturing practices by the staff are also allergen sources. On the other hand, sharing storage areas and transportation of both products increase the risk $[10,11]$.
Due to the different potential routes for the inclusion of allergens in food, companies must take preventive actions in all stages of the process to avoid contamination with allergens or properly label foods. As a principal control measure, the manufacturer must review adequately the raw materials and verify their composition with the suppliers because some ingredients may contain allergens. On the other hand, this review should include the packaging material, a possible source of allergens as well, such as wheat starch due to its use to prevent sticking on the paperboard. Therefore, it is necessary that suppliers provide a certificate of their materials to support they are free-allergens [12].

Another control measure is to prevent cross-contamination with allergens by taking different actions such as verification of proper cleaning in production process involving allergens, setting different colors for differentiating utensils such as containers, ladles, sampling material, among other whishes that could be in contact with allergens; wearing impermeable clothing to reduce the possibility of allergens being transferred by adherence to clothing, using exclusive production lines for foods with allergens, placing barriers that prevent allergen transfer, and controlling flow of air in facilities [13].

The non-compliant product to be reprocessed must be controlled with adequate documentation for traceability purposes. The most acceptable way to use reprocessing material, especially in materials containing allergens, is to separate them from free-allergens products and just mix "the same with the same".

Personnel training on allergens and prevention of crosscontamination are an important control measure to prevent the entry of food allergens; personnel should know how to segregate allergen-containing materials during the stages of receipt of raw materials, storage, processing and even transportation.

Special care should consider with personnel who occasionally have access to production areas such as contractors, visitors, and temporary employees [14].

\section{Food Allergens Detection}

The detection of allergens can be a really difficult task because many times the diverse thermal treatments to which the food are put through can cause the decrease and even increase the allergenic properties of some proteins in foodstuff [15].

The different sources of allergen inclusion in foods make it necessary to have an adequate program to verify the absence of allergens in finished products. Companies usually hire an external provider for the analysis and sometimes this is realized for the manufacturing enterprises that produce the food. Although there are several methods for detecting allergens such as PCR, ELISA or Western Blot there are other methods 
as rapid kits that do not have enough precision [16]. However, analysis of some ingredients derived from allergen poses serious challenges, because some problematic ingredients include oils and lecithin due to their oily nature, hydrolyzed proteins and residues of allergenic growth substrates in gums, starter cultures, enzymes, etc. [9]. Sampling is another problem for the correct detection of allergens because this is not always homogeneously distributed in the food [17].

\section{Conclusion}

The food market around the world demands to industries a right and precise control of allergens through a series of activities that involve different phases in food processing. Food companies must be required to comply with current legislation on allergen-related labeling, mainly in those countries where these products can be commercialized to guarantee consumer safety through a clear identification of allergens. So far, proper management of food allergens is one of the most important challenges for the food industry.

\section{References}

1. Gendel SM, Khan N, Yajnik M (2013) A survey of food allergen control practices in the U.S. food industry. J Food Prot 76(2): 302-306.

2. Boyce JA, Assa'ad A, Burks AW, Jones SM, Sampson HA, et al. (2011) Guidelines for the Diagnosis and Management of Food Allergy in the United States: Summary of the NIAID-Sponsored Expert Panel Report. Nutr Res 31(1): 61-75.

3. Taylor SL, Moneret-Vautrin DA, Crevel RW, Sheffield D, Morisset M, et al. (2010) Threshold dose for peanut: Risk characterization based upon diagnostic oral challenge of a series of 286 peanut-allergic individuals. Food Chem Toxicol 48(3): 814-819.

4. Hefle SL, Nordlee JA, Taylor SL (1996) Allergenic foods. Crit Rev Food Sci Nutr 36(Supplement): 69S-89S.
5. Gendel SM (2012) Comparison of international food allergen labeling regulations. Regul Toxicol Pharmacol 63(2): 279-285.

6. CODEX (1999) Codex general standard for the labelling of prepackaged foods. CODEX STAN 1-1985, Revis 1-1991, 1999: 1-7.

7. Akiyama H, Imai T, Ebisawa M (2011) Japan Food Allergen Labeling Regulation-History and Evaluation. Adv Food Nutr Res. 62: 139-171.

8. European Commission Food Information to Consumers - Legislation.

9. Koppelman S, Hefle S (2006) Detecting Allergens in Food. Woodhead Publishing Ltd, UK.

10. Allen KJ, Turner PJ, Pawankar R, Taylor S, Sicherer S, et al. (2014) Precautionary labelling of foods for allergen content: are we ready for a global framework? World Allergy Organ J 7(1):10.

11. University of Nebraska (2008) Componentes de un plan eficaz de control de alérgenos.

12. Dzwolak W (2017) Assessment of food allergen management in small food facilities. Food Control 73: 323-331.

13. Baumert JL, Tran DH (2015) Handbook of Food Allergen Detection and Control ( $1^{\text {st }}$ edn), Woodhead Publishing, Waltham MA, USA, pp. 219228.

14. Gojkovic V, Marjanovic-Balaban, Z, Vukic M, Grujić R., \& Novaković B (2015) Allergens management system in the food production. J Hyg Eng Des 12: 76-84.

15. Alves RC, Barroso MF, González-García MB, Oliveira MB, Delerue-Matos C (2016) New Trends in Food Allergens Detection: Toward Biosensing Strategies. Crit Rev Food Sci Nutr 56(14): 2304-2319.

16. Van Hengel AJ (2007) Food allergen detection methods and the challenge to protect food-allergic consumers. Anal Bioanal Chem 389(1): 111-118.

17. Röder M, Baltruweit I, Gruyters H, Ibach A, Mücke I, et al. (2010) Allergen sanitation in the food industry: a systematic industrial scale approach to reduce hazelnut cross-contamination of cookies. J Food Prot 73(9): 1671-1679.

\section{Your next submission with Juniper Publishers will reach you the below assets}

- Quality Editorial service

- Swift Peer Review

- Reprints availability

- E-prints Service

- Manuscript Podcast for convenient understanding

- Global attainment for your research

- Manuscript accessibility in different formats ( Pdf, E-pub, Full Text, Audio)

- Unceasing customer service

Track the below URL for one-step submission https://juniperpublishers.com/online-submission.php 